\title{
Influence of Organic, Npk, Bio-Fertilization and Natural Substances Treatments on Black Cumin Plants
}

\author{
Abdou, M.A.H. 1, Taha, R.A. 1, Salah El-Deen, R.M. 1 and Abd-El-Raaof, R.M. 2 \\ 1Dept. of Hort. Fac. of Agric., Minia Univ, 2Hort. Res. Inst., Agric. Res. Center, Giza, Egypt.
}

Nigella sativa, L. plants were fertilized with NPK or 5, 10 and $15 \mathrm{~m} 3 /$ fed. Chicken manure. Inorganic and organic fertilizer represented the main plot. The sub plot treatments were royal jelly (200 and $300 \mathrm{ppm}$ ) salicylic acid (100 and 200) and active dry yeast (5 and $10 \mathrm{~g} / \mathrm{l})$ as well as control. The obtained results showed the following black cumin fertilized with mineral NPK exhibited the best vegetative growth parameters and the highest number of capsule / plant, seed yield / plant and / fed., volatile oil \% and yield / plant and / fed., fixed oil (\% and yield / plant and / fed.), as well as, N, P and K \% in the leaves. Chicken manure treatments significantly decreased all previous parameters as compared with mineral NPK, except high level of chicken manure (15 $\mathrm{m} 3$ /fed.) which resulted the lowest reduction without significant differences between it and mineral NPK treatment. All spraying treatments significantly increased all previous parameters over the untreated (control). Among six used treatments, the treatments of royal jelly (300 ppm) followed by active dry yeast $(10 \mathrm{~g} / \mathrm{l})$ then salicylic acid (200 ppm) resulted the highest values of vegetative growth traits and seed yield ,as well as, oil yield (volatile and fixed) and $\mathrm{P} \%$ in the leaves. Active dry yeast at $10 \mathrm{~g} / \mathrm{l}$ gave the highest percentages of $\mathrm{N}$ and $\mathrm{K}$ in the dry leaves comparing with other treatments. The interaction between main-plot and sub-plot was the most effective on the previous parameters. The highest values in all measurements were obtained due to mineral NPK or high level of chicken manure (15 m3/fed.) in combination with royal jelly (300 ppm), active dry yeast (10 g/l) or salicylic acid (200 ppm).

Key word: Nigella sativa, active dry yeast, royal jelly, chicken manure, volatile oil and fixed oil.

\section{Introduction}

Black cumin (Nigella sativa, L.) plants belong to family Rununculaceae. The black cumin seeds contain $1-1.5 \%$ of volatile oil and $30-35 \%$ of fixed oil which has several uses for pharmaceutical and food industries (Ustun et al., 1999).

The important role of chemical fertilizers is fully recognized. Recently, great attention has been focused on the possibility of using natural and safety substitutes, i.e. organic materials, royal jelly, salicylic acid and active dry yeast in order to improve plant growth, fruit setting and yield.

Some authors studied the effect of organic manure treatments on growth, yield, oil (volatile and fixed) and chemical composition of black cumin as Shalan (2005); Ahmed (2007) and Helmy (2008) who demonstrated that organic fertilization treatments significantly increased vegetative growth traits, seed yield oil parameters (volatile and fixed), as well as, chemical constituents compared with the control.

The effect of organic manure treatments on improving growth and productivity was shown by Mohamed and Ahmed (2002) and Mohamed and Abdou (2004) on fennel plants; Aly et al. (2007a and 2007b) and Abdalla (2009) Corianderum sativum and Hemdan (2008) on anise plants.

Royal jelly is secreted from glands on the heads of worker bees. It is synthesized from pollen, water and honey mixed with saliva, hormones and vitamins. Royal jelly contains 65.3 \% water and 34.7
\% dry residue. The later is composed from $48.2 \%$ proteins, $37.8 \%$ carbohydrates, $10.4 \%$ lipids and 2 $\%$ ash. Royal jelly also contains the vitamins B1, B2, B6, B12 and C. Royal jelly is one of the richest natural products in amino acids. It contains at least 17 amino acids including 8 essential ones. Amino acids are very important for enhancing growth, sex ratio percentage, yield and its components. Royal jelly is also rich in minerals, especially potassium, magnesium, calcium, iron, phosphorus, sulfur, manganese and silicon (Heyl, 1949; Nation and Robinson, 1971).

El-Maziny and Hassan (1990) and El-Shaikha (2010) found that the foliar spray of cucumber cultivars with various concentrations of royal jelly significantly increased vegetative growth traits, sex ratio \% and total fruits yield in comparison with the control treatment.

The effect of active dry yeast on improving growth and productivity was shown by Naguib and Khalil (2002); Ahmed (2007) and Helmy (2008) on Nigella Sativa; Aly, et al. (2007b) on Corianderum sativum and Ahmed (2007) and Hemdan (2008) on anise plants.

Many authors studied the effect of salicylic acid treatments on growth, yield and chemical composition of medicine and aromatic plants as Ali (2004) on Tagetes minuta; Al-Shareif (2006) and Abdou et al. (2009a) on caraway plants, Ayat (2007) on coriander plants, Hemdan (2008) on anise plants; Helmy (2008) on black cumin; Abdou et al. (2009b) on fennel plants, as they all demonstrated that 
salicylic acid at $100 \mathrm{ppm}$ as a foliar spray significantly increased vegetative growth traits, fruit yield, volatile oil parameters, as well as, chemical constituents compared with control.

The object of this study was to investigate the influence of organic, NPK, bio-fertilization and some treatments of safe natural substances, as well as, their interactions on vegetative growth, fruit yield, oil yield (volatile and fixed) and some chemical constituents of black cumin plants.

\section{Materials and Methods}

This investigation was carried out in the Experimental Farm and Laboratory of Faculty of Agriculture, Minia University during the two successive seasons 2009/2010 and 2010/2011 to study the influence of organic, NPK, bio-fertilization and some safe natural substances treatments on Nigella sativa, L. plants.
The experiment was arranged in a randomized complete block design in a split-plot design with three replicates. The main plots (A) included four treatments of NPK and chicken manure at three levels, while seven treatments (royal jelly, salicylic acid and active dry yeast, each at two concentrations, as well as control) occupied the sub plots (B), therefore, the interaction treatments $(A \times B)$ were 28 treatments.

Seeds of black cumin were obtained from Sids Horticultural Research Station, Agric. Research Center, Beni-Suef Governorate and were sown on September 25th of both experimental seasons. The experimental unit (plot) was $1.8 \times 3.0$ meter and containing 3 rows, $60 \mathrm{~cm}$ apart and seeds were cultivated in hills spaced at $30 \mathrm{~cm}$. and each plot contained 60 plants and plants were thinned to two plants / hill after 5 weeks from sowing date. The physical and chemical analysis of the soil is shown in Table (a).

Table a. Physical and chemical characters of the soil used.

\begin{tabular}{|c|c|c|c|c|}
\hline Soil character & Value & \multicolumn{2}{|c|}{ Soil character } & Value \\
\hline Sand \% & 28.2 & \multicolumn{2}{|c|}{ Total N \% } & 0.08 \\
\hline Silt \% & 30.7 & \multicolumn{2}{|c|}{ Available P \% } & 15.12 \\
\hline Clay \% & 41.1 & \multicolumn{2}{|c|}{ Exch. $\mathrm{K}^{+}(\mathrm{mg} / 100 \mathrm{~g})$} & 2.11 \\
\hline Soil texture & Clay loam & \multicolumn{2}{|c|}{ Exch. $\mathrm{Ca}^{++}(\mathrm{mg} / 100 \mathrm{~g})$} & 31.74 \\
\hline Organic matter \% & 1.62 & \multicolumn{2}{|c|}{ Exch. Na $(\mathrm{mg} / 100 \mathrm{~g})$} & 2.4 \\
\hline $\mathrm{CaCO}_{3} \%$ & 2.09 & \multirow{4}{*}{$\begin{array}{l}\text { DTPA } \\
\text { (ppm) }\end{array}$} & $\mathrm{Fe}$ & 8.54 \\
\hline pH 1:2.5 & 7.82 & & $\mathrm{Cu}$ & 2.06 \\
\hline \multirow[t]{2}{*}{ E.C. (m mhos/cm) } & 1.04 & & $\mathrm{Zn}$ & 2.75 \\
\hline & & & $\mathrm{Mn}$ & 8.26 \\
\hline
\end{tabular}

The main plots included four fertilization treatments which were conducted as follows:

$\mathrm{a}_{1^{-}}$NPK: control treatment fertilized with recommended mineral NPK, $200 \mathrm{~kg} / \mathrm{fed}$. of ammonium nitrate $(33.5 \% \mathrm{~N}), 150 \mathrm{~kg} / \mathrm{fed}$. of superphosphate (15.5\% P2O5) and $100 \mathrm{~kg} / \mathrm{fed}$. of potassium sulphate (48 \% K2O). a2- $5 \mathrm{~m} 3 /$ fed., a3$10 \mathrm{~m} 3 / \mathrm{fed}$. and a4- $15 \mathrm{~m} 3 / \mathrm{fed}$. of chicken manure. Chicken manure and mineral phosphorus were added during soil preparation for cultivation in both seasons. The chemical analysis of chicken manure is shown in Table (b). Mineral $\mathrm{N}$ and $\mathrm{K}$ were divided into three equal batches and added at one-month interval, starting from October 31th in both seasons.

The sub plots (B) were devoted to seven treatments; control royal jelly (R1) at $200 \mathrm{ppm}$, royal jelly (R2) at $300 \mathrm{ppm}$, Salicylic acid (SAL1) at $100 \mathrm{ppm}$, Salicylic acid (SAL2) at $200 \mathrm{ppm}$, active dry yeast (ADY1) at $5 \mathrm{~g} / \mathrm{l}$ and active dry yeast (ADY2) at 10 g/l.

The plants were sprayed with the three substances three times at one-month interval, starting from October 31th. Control plants were sprayed with distilled water. All other agricultural practices were carried out as prevailing in the region.

At the termination of the experiments, on the last week of April, the following data were recorded:-

- Vegetative growth characters: - plant height $(\mathrm{cm})$, stem diameter $(\mathrm{cm})$, number of branches/plant and herb dry weight (g/plant).

- Yield and its component: - number of capsules / plant, seed yield (g) /plant, also seed yield (kg / fed.) was calculated.

- Oil determination: - volatile oil \% of seeds according to British pharmacopeia (1963), volatile oil yield (ml/plant and liter/fed.). Also, fixed oil \% of seeds according to A.O.A.C. (1980), fixed oil yield (ml/plant and liter/fed.)

- Chemical analysis : - nitrogen \% was determinated by Micro-kjeldahel method as described by A.O.A.C. (1980) phosphorus \% was determinated colometrically using the method described by Jackson (1973), while potassium \% was estimated using flame-photometry method according to Cotteine et al. (1982). 
The obtained data were statistically analyzed between means were tested using L.S.D. at $5 \%$ level according to M STAT-C (1986). The differences

Table b. Chemical analysis of chicken manure applied in the present study.

\begin{tabular}{|c|c|c|c|c|c|c|c|c|c|c|c|c|}
\hline $1^{\text {st }}$ season & 61.38 & 35.36 & 2.89 & 12.24 & 7.89 & 0.86 & 1.71 & 2610.3 & 336.2 & 297.2 & 7.13 & 1.69 \\
\hline 2nd season & 59.41 & 34.85 & 2.95 & 11.82 & 7.91 & 0.88 & 1.83 & 2011.2 & 341.3 & 301.8 & 7.25 & 1.54 \\
\hline
\end{tabular}

\section{Results and Discussion}

\section{A:-Effect of vegetative growth traits}

Data presented in Tables (1 and 2) revealed that all three used chicken manure treatments decreased plant height, stem diameter, number of branches per plant and herb dry weight / plant, in the two seasons, in comparison with the mineral NPK (recommended dose) treatment. There were significant differences in the aforementioned parameters due to fertilizing with chicken manure. However, non-significant differences were obtained from black cumin plants treated with chicken manure at high level (15 m3/fed.) in comparison with mineral NPK.

The treatments of mineral NPK and high level of chicken manure gave the highest values of vegetative growth traits in comparison with the two other organic fertilization treatments; this may be due to the increase of macro-elements in the root zone in chemical fertilizer and decomposition of chicken manure at high level.

The above results are in an agreement with those obtained by Aly et al. (2007a) and Abdalla (2009) on coriander plants, Abdou et al. (2009a) on caraway plant which stated that application of NPK (200 $+300+100 \mathrm{~kg} / \mathrm{fed}$.) was the most effective rate for increasing vegetative growth traits of Carum carvi, and Shalan (2005) ; Ahmed (2007) on black cumin and Abdalla (2009) on coriander plants who found that the highest values for plant height, number of branches/plant and herb dry weight/plant were obtained when organic manure was applied at high level ( $25 \mathrm{~m} 3 /$ fed. cattle manure).

Data in Tables (1 and 2) showed that plant height, stem diameter, number of branches/plant and herb dry weight/plant were significantly increased due to royal jelly, salicylic acid and active dry yeast (each at two concentrations) treatments over control (without treated) in both seasons. The highest values for the four characters were obtained when plants were treated with royal jelly at high concentration (R2, $300 \mathrm{ppm}$ ) followed by active dry yeast at high concentration (ADY2, $10 \mathrm{~g} / \mathrm{l}$ ) then salicylic acid at high concentration (SAL2, $200 \mathrm{ppm}$ ). In addition, no significant differences were detected between R2 and
ADY2 treatments in all cases, and between R2 and SAL2 treatments in some cases.

The augmentation occurred in the four previous parameters obtained in this study as a result of R2 may be due to any of its components as amino acids, vit. B, some minerals and hormonal status of royal jelly on growth which has been already reported by Heyl (1949); Nation and Robinson (1971); ElMaziny and Hassan (1990) and El-Shaikha (2010). In addition, the stimulatory effects of ADY and/or any of its components as cytokinin and vitamin B on plant growth have been reported by Haridi (1987) on Salvia officinalis; Bowe et al. (1989) on Pelargonium zonal; Naguib and Khalil (2002); Ahmed (2007) and Helmy (2008) on Nigella sativa. While, Hemdan (2008) on anise plants; Helmy (2008) on black cumin and Abdou et al. (2009a) stated that foliar application of salicylic acid at 150 ppm increased plant height, stem diameter, branches number / plant and herb dry weight/plant in comparison with control plants.

The interaction between main-plot and sub-plot was significant for plant height, number of branches/plant and herb dry weight/plant in both seasons. The highest values were obtained by mineral NPK or chicken manure (15 m3/fed.) in combination with R2, ADY2 or SAL2, while the least values in this respect were of the interaction between zero (without any treated) $\times$ chicken manure $5 \mathrm{~m} 3 /$ fed.

\section{B:-Effect of yield parameters-}

Data in Tables (3 and 4) showed that all treatments of chicken manure in the two seasons, gave significantly lower number of capsules/plant, seed yield (g/plant and $\mathrm{kg} / \mathrm{fed}$.) in comparison with mineral NPK, except the treatment of high level of chicken manure (15 m3/fed.) there was nonsignificant differences between it and mineral NPK in both seasons for the three previous characters.

The role of NPK fertilization treatment on increasing yield parameters may be due to the important roles played by the different nutrients $(\mathrm{N}$, $\mathrm{P}$ and $\mathrm{K}$ ) in the different physiological processes within the plant, which in turn affect plant growth, 
consequently yield production. Nitrogen is present in the structure of protein molecules, while phosphorus is an essential constituents of nucleic acids and phospholipids, and potassium is essential as an activator for enzymes involved in the synthesis of certain peptide bonds (Develin, 1975). Also, stimulatory effect of chicken manure at high level (15 m3/fed.) on yield parameters can be explained by the important roles of organic fertilizer which gave better growth, as well as, better photosynthesis consequently more carbohydrates and dry matter accumulation.

The great effect of NPK on yield parameters was noticed by Aly et al., (2007a) and Abdalla (2009) on coriander plants, Helmy (2008) on black cumin and Abdou et al., (2009a) on caraway plants. While, the beneficial effects of chicken manure (15 m3/fed.) obtained in the present study were also detected by Shalan (2005) and Ahmed (2007) on black cumin and Abdou et al. (2009b) on fennel plants.

Table 1. Influence of organic, NPK and bio-fertilization as well as natural substances on plant height (cm) and stem diameter (cm) of Nigella sativa, L. plants.

\begin{tabular}{|c|c|c|c|c|c|c|c|c|c|c|}
\hline \multirow{3}{*}{$\begin{array}{l}\text { Spraying } \\
\text { treatments } \\
\text { (B) }\end{array}$} & \multicolumn{10}{|c|}{ Chicken manure $\left(\mathrm{m}^{3} /\right.$ fed. $)(\mathrm{A})$} \\
\hline & \multicolumn{5}{|c|}{ First season $(2009 / 2010)$} & \multicolumn{5}{|c|}{ Second season $(2010 / 2011)$} \\
\hline & NPK & $5 \mathrm{~m}^{3} / \mathrm{fed}$ & $\begin{array}{c}10 \\
\mathrm{~m}^{3} / \text { fed }\end{array}$ & $\begin{array}{c}15 \\
\mathrm{~m}^{3} / \text { /fed }\end{array}$ & $\begin{array}{l}\text { Mean } \\
\text { (B) }\end{array}$ & NPK & $\begin{array}{c}5 \\
\mathrm{~m}^{3} / \mathrm{fed}\end{array}$ & $\begin{array}{c}10 \\
\mathrm{~m}^{3} / \mathrm{fed}\end{array}$ & $\begin{array}{c}15 \\
\mathrm{~m}^{3} / \text { fed }\end{array}$ & $\begin{array}{c}\text { Mean } \\
(\mathrm{B})\end{array}$ \\
\hline & \multicolumn{10}{|c|}{ Plant height $(\mathrm{cm})$} \\
\hline Control & 44.10 & 40.23 & 43.10 & 44.00 & 42.86 & 45.60 & 41.54 & 44.50 & 45.50 & 44.29 \\
\hline R1 (200 ppm) & 49.43 & 45.00 & 48.20 & 49.33 & 48.14 & 50.90 & 46.93 & 49.60 & 50.81 & 49.56 \\
\hline R2 (300 ppm) & 55.57 & 50.80 & 53.40 & 55.43 & 53.80 & 58.21 & 51.12 & 54.85 & 57.95 & 55.53 \\
\hline SAL1 (100 ppm) & 49.47 & 45.73 & 48.33 & 49.40 & 48.24 & 50.97 & 46.01 & 49.74 & 50.91 & 49.41 \\
\hline SAL2 (200 ppm) & 52.33 & 49.37 & 51.97 & 52.10 & 51.44 & 54.30 & 50.68 & 53.38 & 53.83 & 53.10 \\
\hline $\mathrm{Y} 1(5 \mathrm{~g} / \mathrm{l})$ & 49.21 & 45.40 & 48.00 & 49.00 & 47.90 & 50.83 & 46.71 & 49.45 & 50.51 & 49.38 \\
\hline Y2 $(10 \mathrm{~g} / \mathrm{l})$ & 52.70 & 49.47 & 52.07 & 52.30 & 51.64 & 54.90 & 50.79 & 53.49 & 53.65 & 53.15 \\
\hline $\operatorname{Mean}(\mathrm{A})$ & 50.40 & 46.66 & 49.30 & 50.22 & & 52.24 & 47.68 & 50.72 & 51.88 & \\
\hline \multirow[t]{2}{*}{ L.S.D. at $5 \%$} & \multicolumn{2}{|c|}{\begin{tabular}{l|l} 
A: 0.80 & \\
\end{tabular}} & B: 2.37 & \multicolumn{2}{|c|}{\begin{tabular}{l|l} 
& $A B: 4.74$ \\
\end{tabular}} & \multicolumn{2}{|c|}{ A: 0.80} & B: 2.44 & \multicolumn{2}{|c|}{\begin{tabular}{l|l} 
& AB: 4.88 \\
\end{tabular}} \\
\hline & \multicolumn{10}{|c|}{ Stem diameter $(\mathrm{cm})$} \\
\hline Control & 0.58 & 0.53 & 0.56 & 0.57 & 0.56 & 0.60 & 0.55 & 0.57 & 0.58 & 0.58 \\
\hline R1 (200 ppm) & 0.68 & 0.63 & 0.65 & 0.66 & 0.66 & 0.70 & 0.65 & 0.66 & 0.68 & 0.67 \\
\hline R2 (300 ppm) & 0.76 & 0.70 & 0.72 & 0.75 & 0.73 & 0.78 & 0.71 & 0.75 & 0.77 & 0.75 \\
\hline SAL1 (100 ppm) & 0.69 & 0.66 & 0.66 & 0.67 & 0.67 & 0.73 & 0.67 & 0.68 & 0.71 & 0.70 \\
\hline SAL2 (200 ppm) & 0.74 & 0.67 & 0.71 & 0.72 & 0.71 & 0.75 & 0.68 & 0.72 & 0.74 & 0.72 \\
\hline $\mathrm{Y} 1(5 \mathrm{~g} / \mathrm{l})$ & 0.66 & 0.62 & 0.64 & 0.65 & 0.64 & 0.68 & 0.63 & 0.65 & 0.67 & 0.66 \\
\hline $\mathrm{Y} 2(10 \mathrm{~g} / \mathrm{l})$ & 0.75 & 0.68 & 0.71 & 0.74 & 0.72 & 0.76 & 0.69 & 0.73 & 0.75 & 0.73 \\
\hline Mean $(\mathrm{A})$ & 0.69 & 0.64 & 0.66 & 0.68 & & 0.71 & 0.65 & 0.68 & 0.70 & \\
\hline L.S.D. at $5 \%$ & \multicolumn{2}{|c|}{ A: 0.01} & B: 0.02 & \multicolumn{2}{|c|}{ AB: N.S. } & \multicolumn{2}{|c|}{ A: 0.01} & B: 0.02 & \multicolumn{2}{|c|}{ AB: N.S } \\
\hline R: Royal jelly & $\mathrm{SA}$ & : Salicy & acid & $\mathrm{Y}:$ Actil & dry yea & & & & & \\
\hline
\end{tabular}

Table 2. Influence of organic, NPK and bio-fertilization as well as natural substances on number of branches / plant and herb dry weight / plant (g) of Nigella sativa, L. plants.

\begin{tabular}{|c|c|c|c|c|c|c|c|c|c|c|}
\hline \multirow{3}{*}{$\begin{array}{l}\text { Spraying } \\
\text { treatments } \\
\text { (B) }\end{array}$} & \multicolumn{10}{|c|}{ Chicken manure ( $\mathrm{m}^{3} /$ fed.) (A) } \\
\hline & \multicolumn{5}{|c|}{ First season $(2009 / 2010)$} & \multicolumn{5}{|c|}{ Second season $(2010 / 2011)$} \\
\hline & NPK & $5 \mathrm{~m}^{3} /$ fed & $\begin{array}{c}10 \\
\mathrm{~m}^{3} / \text { fed }\end{array}$ & $\begin{array}{c}15 \\
\mathrm{~m}^{3} / \mathrm{fed}\end{array}$ & $\begin{array}{c}\text { Mean } \\
\text { (B) }\end{array}$ & NPK & $\begin{array}{c}5 \\
\mathrm{~m}^{3} / \mathrm{fed}\end{array}$ & $\begin{array}{c}10 \\
\mathrm{~m}^{3} / \text { fed }\end{array}$ & $\begin{array}{c}15 \\
\mathrm{~m}^{3} / \mathrm{fed}\end{array}$ & $\begin{array}{c}\text { Mean } \\
\text { (B) }\end{array}$ \\
\hline & \multicolumn{10}{|c|}{ Number of branches / plant } \\
\hline Control & 7.67 & 6.55 & 7.41 & 7.53 & 7.29 & 7.95 & 6.61 & 7.45 & 7.63 & 7.41 \\
\hline R1 (200 ppm) & 9.25 & 8.09 & 8.76 & 9.00 & 8.78 & 9.43 & 8.15 & 9.07 & 9.30 & 8.99 \\
\hline R2 (300 ppm) & 11.23 & 9.83 & 10.94 & 11.10 & 10.78 & 11.45 & 9.95 & 11.05 & 11.31 & 10.94 \\
\hline SAL1 (100 ppm) & 9.81 & 8.83 & 9.25 & 9.71 & 9.40 & 10.11 & 9.00 & 9.46 & 9.95 & 9.63 \\
\hline SAL2 (200 ppm) & 10.21 & 9.05 & 9.68 & 10.00 & 9.74 & 10.55 & 9.23 & 10.00 & 10.34 & 10.03 \\
\hline $\mathrm{Y} 1(5 \mathrm{~g} / \mathrm{l})$ & 8.64 & 7.75 & 8.38 & 8.50 & 8.32 & 8.72 & 8.06 & 8.43 & 8.61 & 8.46 \\
\hline $\mathrm{Y} 2(10 \mathrm{~g} / \mathrm{l})$ & 10.33 & 9.48 & 9.81 & 10.30 & 9.98 & 10.89 & 9.68 & 10.25 & 10.75 & 10.39 \\
\hline Mean $(\mathrm{A})$ & 9.59 & 8.51 & 9.18 & 9.45 & & 9.87 & 8.67 & 9.39 & 9.70 & \\
\hline \multirow[t]{2}{*}{ L.S.D. at $5 \%$} & \multicolumn{2}{|c|}{ A: 0.15} & \multirow[t]{2}{*}{ B: 0.9} & \multicolumn{2}{|c|}{ AB: 1.8} & \multicolumn{2}{|c|}{ A: 0.18} & \multirow[t]{2}{*}{ B: 0.93} & \multicolumn{2}{|c|}{ AB: 1.86} \\
\hline & \multicolumn{8}{|c|}{ Herb dry weight / plant $(g)$} & & \\
\hline Control & 36.90 & 34.81 & 35.95 & 36.64 & 36.08 & 37.82 & 34.92 & 36.65 & 37.11 & 36.63 \\
\hline R1 (200 ppm) & 51.70 & 47.16 & 48.62 & 49.85 & 49.33 & 52.96 & 47.27 & 49.84 & 52.75 & 50.71 \\
\hline R2 (300 ppm) & 63.97 & 61.12 & 62.05 & 63.09 & 62.56 & 64.18 & 61.24 & 63.10 & 63.95 & 63.12 \\
\hline SAL1 (100 ppm) & 54.31 & 51.31 & 52.43 & 54.00 & 53.01 & 55.11 & 51.41 & 54.01 & 54.89 & 53.86 \\
\hline SAL2 (200 ppm) & 57.43 & 55.00 & 56.31 & 57.01 & 56.44 & 58.25 & 55.11 & 57.00 & 58.10 & 57.12 \\
\hline Y1 (5 g/l) & 49.73 & 46.65 & 47.66 & 49.13 & 48.29 & 50.15 & 46.85 & 49.12 & 49.81 & 48.98 \\
\hline Y2 (10 g/l) & 59.80 & 56.95 & 58.95 & 59.10 & 58.70 & 60.23 & 58.82 & 59.12 & 60.00 & 59.54 \\
\hline Mean $(\mathrm{A})$ & 53.41 & 50.43 & 51.71 & 52.69 & & 54.10 & 50.80 & 52.69 & 53.80 & \\
\hline L.S.D. at $5 \%$ & \multicolumn{2}{|c|}{ A: 0.74} & B: 3.88 & \multicolumn{2}{|c|}{\begin{tabular}{l|l} 
& AB: 7.76
\end{tabular}} & \multicolumn{2}{|c|}{ A: 0.81} & B: 8.65 & \multicolumn{2}{|c|}{\begin{tabular}{l|l} 
& AB: 7.30
\end{tabular}} \\
\hline
\end{tabular}


Table 3. Influence of organic, NPK and bio-fertilization as well as natural substances on capsule number/plant and seeds weight / plant (g) of Nigella sativa, L. plants.

\begin{tabular}{|c|c|c|c|c|c|c|c|c|c|c|}
\hline \multirow{2}{*}{$\begin{array}{l}\text { Spraying } \\
\text { treatments } \\
\text { (B) }\end{array}$} & \multicolumn{10}{|c|}{ Chicken manure ( $\mathrm{m}^{3} /$ fed.) (A) } \\
\hline & \multicolumn{5}{|c|}{ First season $(2009 / 2010)$} & \multicolumn{5}{|c|}{ Second season $(2010 / 2011)$} \\
\hline Control & 39.17 & 31.26 & 36.08 & 37.34 & 35.96 & 42.67 & 31.50 & 36.21 & 37.68 & 37.02 \\
\hline R1 (200 ppm) & 50.07 & 43.66 & 47.60 & 49.80 & 47.78 & 50.68 & 43.81 & 47.85 & 50.12 & 48.12 \\
\hline R2 (300 ppm) & 65.50 & 59.43 & 63.50 & 65.00 & 63.36 & 65.00 & 59.05 & 63.10 & 64.60 & 62.94 \\
\hline Y1 (5 g/l) & 47.67 & 41.37 & 45.83 & 47.10 & 45.49 & 47.95 & 41.87 & 46.02 & 47.34 & 45.80 \\
\hline Y2 (10 g/l) & 57.77 & 51.16 & 55.85 & 57.12 & 55.48 & 58.42 & 51.68 & 56.15 & 58.00 & 56.07 \\
\hline Mean (A) & 53.07 & 49.29 & 50.68 & 52.40 & & 54.02 & 46.60 & 50.82 & 52.90 & \\
\hline \multirow[t]{2}{*}{ L.S.D. at $5 \%$} & \multicolumn{2}{|c|}{ A: 1.51} & B: 2.5 & \multicolumn{2}{|c|}{ AB: 5.00} & \multicolumn{2}{|c|}{$\mathrm{A}: 1.8$} & B: 2.9 & \multicolumn{2}{|c|}{ AB: 5.8} \\
\hline & \multicolumn{10}{|c|}{ Seeds weight / plant $(g)$} \\
\hline SAL2 (200 ppm) & 13.89 & 10.25 & 12.22 & 13.81 & 12.54 & 14.17 & 10.47 & 12.32 & 13.95 & 12.73 \\
\hline $\mathrm{Y} 1(5 \mathrm{~g} / \mathrm{l})$ & 11.70 & 8.97 & 10.80 & 11.64 & 10.78 & 12.09 & 9.02 & 10.99 & 12.00 & 11.03 \\
\hline Y2 (10 g/l) & 14.05 & 10.57 & 12.95 & 14.00 & 12.89 & 14.21 & 10.79 & 13.02 & 14.09 & 13.03 \\
\hline Mean (A) & 12.97 & 9.46 & 11.61 & 12.81 & & 13.25 & 9.58 & 11.69 & 12.92 & \\
\hline L.S.D. at $5 \%$ & \multicolumn{2}{|c|}{ A: 0.74} & B: 0.8 & \multicolumn{2}{|c|}{ AB: 1.6} & \multicolumn{2}{|c|}{ A: 0.37} & B: 1.03 & \multicolumn{2}{|c|}{\begin{tabular}{l|l} 
& AB: 2.07 \\
\end{tabular}} \\
\hline R: Royal jelly & & : Activ & Iry yeas & & & & & \\
\hline
\end{tabular}

Table 4. Influence of organic, NPK and bio-fertilization as well as natural substances on seeds weight / fed. (kg) and volatile oil \% of Nigella sativa, L. plants.

\begin{tabular}{|c|c|c|c|c|c|c|c|c|c|c|}
\hline \multirow{3}{*}{$\begin{array}{l}\text { Spraying } \\
\text { treatments } \\
\text { (B) }\end{array}$} & \multicolumn{10}{|c|}{ Chicken manure $\left(\mathrm{m}^{3} /\right.$ fed. $)(\mathrm{A})$} \\
\hline & \multicolumn{5}{|c|}{ First season $(2009 / 2010)$} & \multicolumn{5}{|c|}{ Second season (2010/2011) } \\
\hline & NPK & $\begin{array}{c}5 \\
\mathrm{~m}^{3} / \mathrm{fed} .\end{array}$ & \begin{tabular}{|c|}
10 \\
$\mathrm{~m}^{3} /$ fed \\
\end{tabular} & $\begin{array}{c}15 \\
\mathrm{~m}^{3} / \mathrm{fed}\end{array}$ & $\begin{array}{l}\text { Mean } \\
(\mathrm{B})\end{array}$ & NPK & $\begin{array}{c}5 \\
\mathrm{~m}^{3} / \mathrm{fed}\end{array}$ & $\begin{array}{c}10 \\
\mathrm{~m}^{3} / \mathrm{fed} \\
\end{array}$ & $\begin{array}{c}15 \\
\mathrm{~m}^{3} / \mathrm{fed}\end{array}$ & $\begin{array}{c}\text { Mean } \\
(\mathrm{B})\end{array}$ \\
\hline & \multicolumn{10}{|c|}{ Seeds weight / fed. $(\mathrm{kg})$} \\
\hline Control & 454.22 & 283.56 & 364.44 & 424.44 & 381.66 & 498.78 & 286.67 & 378.22 & 428.44 & 398.03 \\
\hline R1 (200 ppm) & 536.89 & 414.22 & 490.22 & 533.33 & 493.67 & 542.67 & 417.33 & 493.33 & 540.89 & 498.56 \\
\hline R2 (300 ppm) & 725.78 & 485.33 & 661.33 & 720.88 & 648.33 & 721.78 & 478.67 & 655.11 & 713.78 & 642.34 \\
\hline SAL1 (100 ppm) & 556.44 & 436.44 & 496.44 & 553.78 & 510.78 & 562.22 & 452.00 & 504.44 & 557.33 & 519.00 \\
\hline SAL2 & 617.33 & 455.56 & 543.11 & 613.78 & 557.45 & 629.78 & 465.33 & 547.56 & 620.00 & 565.67 \\
\hline$Y 1(5 \mathrm{~g} / \mathrm{l})$ & 520.00 & 398.67 & 480.00 & 517.33 & 479.00 & 537.33 & 400.89 & 488.44 & 533.33 & 490.00 \\
\hline Y2 (10 g/l) & 624.44 & 469.78 & 575.55 & 622.22 & 573.00 & 631.55 & 479.56 & 578.67 & 626.22 & 579.00 \\
\hline Mean (A) & 574.44 & 424.37 & 515.87 & 569.40 & & 589.16 & 425.78 & 520.82 & 574.28 & \\
\hline \multirow[t]{2}{*}{ L.S.D. at $5 \%$} & \multicolumn{2}{|c|}{ A: 13.22} & B: 15.18 & \multicolumn{2}{|c|}{ AB: 30.36} & \multicolumn{2}{|c|}{ A: 15.34} & B: 17.11 & \multicolumn{2}{|c|}{ AB: 34.22} \\
\hline & \multicolumn{10}{|c|}{ Volatile oil \% } \\
\hline Control & 1.27 & 1.19 & 1.23 & 1.26 & 1.24 & 1.30 & 1.21 & 1.26 & 1.28 & 1.26 \\
\hline R1 (200 ppm) & 1.37 & 1.26 & 1.30 & 1.36 & 1.32 & 1.40 & 1.28 & 1.35 & 1.37 & 1.35 \\
\hline R2 (30) & 1.41 & 1.31 & 1.35 & 1.40 & 1.37 & 1.45 & 1.34 & 1.39 & 1.43 & 1.40 \\
\hline SAL1 (100 ppm) & 1.38 & 1.28 & 1.32 & 1.37 & 1.34 & 1.42 & 1.31 & 1.36 & 1.38 & 1.37 \\
\hline SAL2 (200 ppm) & 1.41 & 1.32 & 1.36 & 1.40 & 1.37 & 1.46 & 1.34 & 1.41 & 1.44 & 1.41 \\
\hline $\mathrm{Y} 1(5 \mathrm{~g} / \mathrm{l})$ & 1.40 & 1.29 & 1.33 & 1.38 & 1.35 & 1.43 & 1.32 & 1.38 & 1.40 & 1.38 \\
\hline $\mathrm{Y} 2(10 \mathrm{~g} / \mathrm{l})$ & 1.43 & 1.33 & 1.38 & 1.42 & 1.39 & 1.47 & 1.36 & 1.42 & 1.45 & 1.43 \\
\hline Mean (A) & 1.38 & 1.28 & 1.32 & 1.37 & & 1.42 & 1.31 & 1.37 & 1.39 & \\
\hline L.S.D. at $5 \%$ & \multicolumn{2}{|c|}{ A: 0.05} & B: 0.02 & \multicolumn{2}{|c|}{\begin{tabular}{l|l} 
& $A B: 0.04$ \\
\end{tabular}} & \multicolumn{2}{|c|}{ A: 0.04} & B: 0.03 & \multirow{2}{*}{\multicolumn{2}{|c|}{ AB: 0.06}} \\
\hline R: Royal jelly & SAL & : Salicy & c acid & $\mathrm{Y}:$ Act & e dry yea & & & & & \\
\hline
\end{tabular}

Concerning natural substances and ADY treatments, all six treatments gave significantly higher number of capsules/plant and seed yield (g/plant and kg/fed.) than those of untreated control plants. Among these six used treatments; royal jelly at high concentration (300 ppm) gave the most significantly highest values in the two seasons.
Royal jelly gave tremendous effects on all studied variables which may be a result from the content of some hormones, as well as, its nutrition balance (Townsend and Lucas, 1940; Heyl, 1949 and Nation and Robinson, 1971; El-Maziny and Hassan, 1990 and El-Shaikha, 2010).

The interaction between the main two factors $(\mathrm{A} \times \mathrm{B})$ was significant in the two seasons. The 
highest values were obtained due to mineral NPK or chicken manure (at $15 \mathrm{~m} 3 / \mathrm{fed}$.) in combination with royal jelly at $300 \mathrm{ppm}$ as clearly shown in Tables (3 and 4).

\section{C:-Effect on oil productivity}

Data in Tables (4, 5, 6 and 7) showed that volatile oil and fixed oil (percentages and yield/plant and /fed.) were significantly affected by the application of mineral NPK and chicken manure as organic fertilization. Mineral NPK gave the highest values in both seasons. The differences among mineral NPK and chicken manure treatments reached significant levels, except for the treatment of chicken manure at $15 \mathrm{~m} 3$ per feddan.

In accordance with these results concerning NPK were those reported by Aly et al. (2007a) on coriander plants, Helmy (2008) on black cumin plant and Abdou et al., (2009a) on caraway plants. Meantime, some others proved the capability of organic fertilizers in increasing essential oil \% and yield as Abdalla (2009) on coriander and Abdou et al. (2009b) on fennel, or fixed oil \% and yield as Helmy (2008) on black cumin.

Data in Tables (4, 5, 6 and 7) showed that all six used treatments of natural substances (royal jelly, salicylic acid and active dry yeast, each at two concentrations) significantly increased volatile oil and fixed oil (percentages and yield/plant and /fed.). The highest values of volatile oil \% were obtained due to active dry yeast (10 g/l) followed by salicylic acid (200 ppm) or royal jelly (300 ppm), while the treatments of royal jelly (300 ppm) followed by active dry yeast (10 g/l) then salicylic acid (200 ppm) resulted the highest values of volatile oil yield ( $\mathrm{ml}$ / plant and liter / fed.) and fixed oil yield per plant and per feddan without significant differences among them in both seasons for volatile oil (\% and yield) and with significant differences among them in both seasons for fixed oil \% and yield.

Data showed that royal jelly gave tremendous effects on all studied variables which may result from the content of some hormones and its nutrition balance (Townsend and Lucas, 1940, Heyl, 1949, ElMazny and Hassan, 1990; El-Shaikh, 2010).

The various positive effects of applying ADY on growth and oil content obtained in this investigation could be attributed to, it containing natural plant growth regulators (Bowe et al., 1989); and/or higher values of vitamins (Buchula and Schmid, 1979), it aiding the activation of the photosynthesis process through enhancing the release of carbon dioxide produced from fermentation (Larson et al., 1962).
Similar results were obtained by Helmy (2008) on Nigella sativa; Aly et al. (2007b) on coriander and Hemdan (2008) on anise plants.

The enhancing effects of high concentrations of salicylic acid on black cumin plants may be due to the fact that salicylic acid accelerates leaf area and mass production (Khan et al., 2003) and has a direct role in enhancement uptake of ions (Gordon et al., 2002). Similar results have been previously stated by Helmy (2008) on black cumin and Abdou et al. (2009b) on fennel.

The interaction between main-plot and sub-plot was significant for volatile and fixed oil (\% or yield). The highest values of volatile oil \% were obtained due to NPK or chicken manure in combination with Y2, SAL2 or R2. The highest yield of volatile oil were obtained from NPK or chicken manure with R2 or Y2 and SAL2. Regarding fixed oil \%, the interaction treatments of NPK $\times$ Y2 or chicken manure $\times$ Y2 or SAL2 gave the highest values of fixed oil yield were obtained due to mineral NPK $\times$ R2 or Y2 or chicken manure $\times \mathrm{R} 2$ or $\mathrm{Y} 2$.

\section{D:-Effect on $N, P$ and $K$ percentages in the leaves}

Data in Tables (7 and 8) revealed that there were significant decreases in $\mathrm{N}, \mathrm{P}$ and $\mathrm{K}(\%)$ in black cumin leaves due to chicken manure 5 and 10 m3/fed. treatments in comparison with mineral NPK treatment, while the treatment of chicken manure at $15 \mathrm{~m} 3 /$ fed. resulted a least reduction in N, P and $\mathrm{K} \%$ without significant differences between it and mineral NPK treatment in both seasons. These results are in accordance with previous results obtained by Aly et al. (2007b) on coriander plants and Ibrahim (2010) on geranium plants.

With regard to natural substances and ADY treatments, there were significant increases in $\mathrm{N}, \mathrm{P}$ and $\mathrm{K} \%$ in black cumin leaves from all six used treatments in comparison with the untreated control plants in both seasons. The highest values of $\mathrm{N}$ and $\mathrm{K}$ $\%$ in both seasons were obtained from ADY at high rate $10 \mathrm{~g} / \mathrm{l}$. While, the significantly highest values of $\mathrm{K} \%$ were obtained due to R2 and ADY2 treatments. In agreement with our results concerning active dry yeast were those reported by Aly et al. (2007b) on coriander ; Hemdan (2008) on anise and Helmy (2008) on black cumin.

The interaction between main-plot and sub-plot was not significant in both seasons for $\mathrm{N}, \mathrm{P}$ and $\mathrm{k} \%$ as clearly shown in Tables (7 and 8). 
Table 5. Influence of organic, NPK and bio-fertilization as well as natural substances on volatile oil yield/plant and /feddan of Nigella sativa, L. plants.

\begin{tabular}{|c|c|c|c|c|c|c|c|c|c|c|}
\hline \multirow{3}{*}{$\begin{array}{l}\text { Spraying } \\
\text { treatments } \\
\text { (B) }\end{array}$} & \multicolumn{10}{|c|}{ Chicken manure $\left(\mathrm{m}^{3} /\right.$ fed.) $(\mathrm{A})$} \\
\hline & \multicolumn{5}{|c|}{ First season $(2009 / 2010)$} & \multicolumn{5}{|c|}{ Second season (2010/2011) } \\
\hline & NPK & $5 \mathrm{~m}^{3} /$ fed. & $\begin{array}{c}10 \\
\mathrm{~m}^{3} / \text { fed } \\
\end{array}$ & $\begin{array}{c}15 \\
\mathrm{~m}^{3} / \text { fed } \\
\end{array}$ & $\begin{array}{c}\text { Mean } \\
(\mathrm{B}) \\
\end{array}$ & NPK & $\begin{array}{c}5 \\
\mathrm{~m}^{3} / \text { fed. }\end{array}$ & $\begin{array}{c}10 \\
\mathrm{~m}^{3} / \text { fed } \\
\end{array}$ & $\begin{array}{c}15 \\
\mathrm{~m}^{3} / \mathrm{fed}\end{array}$ & $\begin{array}{c}\text { Mean } \\
(B)\end{array}$ \\
\hline & \multicolumn{10}{|c|}{ Oil yield (ml/plant) } \\
\hline Control & 0.13 & 0.08 & 0.10 & 0.12 & 0.11 & 0.14 & 0.08 & 0.10 & 0.12 & 0.11 \\
\hline R1 (200 ppm) & 0.17 & 0.12 & 0.14 & 0.16 & 0.15 & 0.17 & 0.12 & 0.15 & 0.17 & 0.15 \\
\hline SAL2 (200 ppm) & 0.20 & 0.14 & 0.17 & 0.19 & 0.18 & 0.21 & 0.14 & 0.17 & 0.20 & 0.18 \\
\hline $\mathrm{Y} 1(5 \mathrm{~g} / \mathrm{l})$ & 0.16 & 0.12 & 0.14 & 0.16 & 0.15 & 0.17 & 0.12 & 0.15 & 0.17 & 0.15 \\
\hline Y2 (10 g/l) & 0.21 & 0.16 & 0.18 & 0.20 & 0.19 & 0.21 & 0.15 & 0.18 & 0.20 & 0.19 \\
\hline Mean $(A)$ & 0.18 & 0.12 & 0.15 & 0.18 & & 0.19 & 0.13 & 0.16 & 0.18 & \\
\hline L.S.D. at $5 \%$ & \multicolumn{2}{|c|}{ A: 0.02} & B: 0.02 & \multicolumn{2}{|c|}{ AB: 0.04} & \multicolumn{2}{|c|}{ A: 0.02} & \multicolumn{2}{|l|}{ B: 0.02} & AB: 0.04 \\
\hline R2 (300 ppm) & 10.22 & 6.22 & 8.89 & 10.22 & 8.89 & 10.67 & 6.22 & 8.89 & 10.22 & 9.00 \\
\hline SAL1 (100 ppm) & 7.56 & 5.78 & 6.67 & 7.56 & 6.89 & 8.00 & 5.78 & 6.67 & 7.56 & 7.00 \\
\hline SAL2 (200 ppm) & 8.89 & 6.22 & 7.56 & 8.44 & 7.78 & 9.33 & 6.22 & 7.56 & 8.89 & 8.00 \\
\hline Y1 (5 g/l) & 7.11 & 5.33 & 6.22 & 7.11 & 6.44 & 7.56 & 5.33 & 6.67 & 7.56 & 6.78 \\
\hline Y2 (10 g/l) & 8.89 & 6.22 & 8.00 & 8.89 & 8.00 & 9.33 & 6.67 & 8.00 & 8.89 & 8.22 \\
\hline Mean $(\mathrm{A})$ & 8.00 & 5.52 & 6.86 & 7.81 & & 8.38 & 5.59 & 6.99 & 8.00 & \\
\hline L.S.D. at $5 \%$ & \multicolumn{2}{|c|}{ A: 0.98} & B: 1.12 & \multicolumn{2}{|c|}{ AB: 2.24} & \multicolumn{2}{|c|}{ A: 1.01} & B: 1.01 & \multicolumn{2}{|c|}{$\begin{array}{ll}\mathrm{AB}: 2.02 \\
\end{array}$} \\
\hline
\end{tabular}

Table 6. Influence of organic, NPK and bio-fertilization as well as natural substances on fixed oil \% and fixed oil yield (ml/plant) of Nigella sativa, L. plants.

\begin{tabular}{|c|c|c|c|c|c|c|c|c|c|c|}
\hline \multirow{3}{*}{$\begin{array}{l}\text { Spraying } \\
\text { treatments } \\
\text { (B) }\end{array}$} & \multicolumn{10}{|c|}{ Chicken manure $\left(\mathrm{m}^{3} / \mathrm{fed}\right.$.) (A) } \\
\hline & \multicolumn{5}{|c|}{ First season $(2009 / 2010)$} & \multicolumn{5}{|c|}{ Second season (2010/2011) } \\
\hline & NPK & $5 \mathrm{~m}^{3} / \mathrm{fed}$ & $10 \mathrm{~m}^{3} / \mathrm{fed}$ & $\begin{array}{c}15 \\
\mathrm{~m}^{3} / \mathrm{fed}\end{array}$ & Mean $(B)$ & NPK & $\begin{array}{c}5 \\
\mathrm{~m}^{3} / \mathrm{fed} .\end{array}$ & $\begin{array}{c}10 \\
\mathrm{~m}^{3} / \mathrm{fed}\end{array}$ & $\begin{array}{c}15 \\
\mathrm{~m}^{3} / \mathrm{fed}\end{array}$ & Mean $(B)$ \\
\hline & \multicolumn{10}{|c|}{ Fixed oil \% } \\
\hline Control & 29.08 & 24.57 & 26.68 & 28.57 & 27.23 & 29.45 & 24.98 & 27.10 & 28.95 & 27.62 \\
\hline $\mathrm{R} 1(200 \mathrm{ppm})$ & 30.36 & 26.89 & 29.20 & 30.18 & 29.16 & 31.25 & 27.70 & 30.02 & 30.97 & 29.99 \\
\hline R2 $(300 \mathrm{ppm})$ & 32.65 & 28.21 & 30.70 & 32.59 & 31.04 & 33.40 & 29.16 & 31.65 & 33.35 & 31.89 \\
\hline SAL1 (100 ppm) & 31.25 & 27.49 & 29.89 & 31.10 & 29.93 & 32.11 & 28.30 & 30.64 & 31.98 & 30.76 \\
\hline SAL2 $(200 \mathrm{ppm})$ & 39.21 & 28.70 & 31.20 & 34.19 & 32.08 & 34.85 & 29.68 & 32.18 & 34.75 & 32.87 \\
\hline Y1 (5 g/l) & 32.60 & 27.91 & 30.28 & 32.56 & 30.84 & 33.30 & 28.75 & 30.77 & 33.28 & 31.53 \\
\hline Y2 (10 g/l) & 34.89 & 29.66 & 32.56 & 34.67 & 32.95 & 35.99 & 30.47 & 33.68 & 35.74 & 33.97 \\
\hline Mean $(A)$ & 32.15 & 27.63 & 30.07 & 31.98 & & 32.91 & 28.43 & 30.86 & 32.72 & \\
\hline \multirow[t]{2}{*}{ L.S.D. at $5 \%$} & \multicolumn{2}{|c|}{ A: 1.6} & B: 0.43 & & AB: 0.86 & & & B: 0.47 & & B: 0.94 \\
\hline & \multicolumn{10}{|c|}{ Fixed oil yield (ml/plant) } \\
\hline Control & 2.97 & 1.57 & 2.19 & 2.73 & 2.37 & 3.30 & 1.61 & 2.25 & 2.79 & 2.09 \\
\hline R1 (200 ppm) & 3.66 & 2.51 & 3.22 & 3.62 & 3.25 & 3.82 & 2.60 & 3.33 & 3.77 & 3.38 \\
\hline R2 $(300 \mathrm{ppm})$ & 5.33 & 3.08 & 4.57 & 5.29 & 4.57 & 5.42 & 3.14 & 4.67 & 5.36 & 4.65 \\
\hline SAL1 (100 ppm) & 3.91 & 2.70 & 3.34 & 3.88 & 3.46 & 4.06 & 2.88 & 3.48 & 4.01 & 3.61 \\
\hline SAL2 (200 ppm) & 4.75 & 2.94 & 3.81 & 4.72 & 4.06 & 4.94 & 3.11 & 3.96 & 4.85 & 4.22 \\
\hline Y1 $(5 \mathrm{~g} / \mathrm{l})$ & 3.81 & 2.50 & 3.27 & 3.79 & 3.34 & 4.03 & 2.59 & 3.38 & 3.99 & 3.50 \\
\hline Y2 (10 g/l) & 4.90 & 3.14 & 4.22 & 4.85 & 4.28 & 5.11 & 3.29 & 4.39 & 5.04 & 4.46 \\
\hline $\operatorname{Mean}(A)$ & 4.19 & 2.28 & 3.52 & 4.13 & & 4.38 & 2.75 & 3.64 & 4.26 & \\
\hline L.S.D. at $5 \%$ & \multicolumn{2}{|c|}{$\mathrm{A}: 0.51$} & \multicolumn{2}{|l|}{ B: 0.28} & $A B: 0.56$ & \multicolumn{2}{|c|}{ A: 0.62} & B: 0.18 & \multirow{2}{*}{\multicolumn{2}{|c|}{$\mathrm{AB}: 0.36$}} \\
\hline R: Royal jelly & SAL. & alicylic aci & $\mathrm{Y}: \mathrm{Act}$ & $\mathrm{dr}$ & east & & & & & \\
\hline
\end{tabular}


Table 7. Influence of organic, NPK and bio-fertilization as well as natural substances on fixed oil yield/feddan and nitrogen percentage of Nigella sativa, L. plants.

\begin{tabular}{|c|c|c|c|c|c|c|c|c|c|c|c|}
\hline \multirow{3}{*}{$\begin{array}{l}\text { Spraying } \\
\text { treatments } \\
\text { (B) }\end{array}$} & \multicolumn{11}{|c|}{ Chicken manure $\left(\mathrm{m}^{3} /\right.$ fed.) $(\mathrm{A})$} \\
\hline & \multicolumn{5}{|c|}{\begin{tabular}{|l|l} 
First season $(2009 / 2010)$ & \\
\end{tabular}} & \multicolumn{6}{|c|}{ Second season $(2010 / 2011)$} \\
\hline & NPK & \begin{tabular}{c|}
5 \\
$\mathrm{~m}^{3} / \mathrm{fed}$
\end{tabular} & \begin{tabular}{|c|}
10 \\
$\mathrm{~m}^{3} / \mathrm{fed}$
\end{tabular} & $\begin{array}{c}15 \\
\mathrm{~m}^{3} / \mathrm{fed}\end{array}$ & \begin{tabular}{|c|}
$\begin{array}{c}\text { Mean } \\
(\mathrm{B})\end{array}$ \\
\end{tabular} & NPK & \begin{tabular}{c|}
5 \\
$\mathrm{~m}^{3} /$ fed.
\end{tabular} & \begin{tabular}{c|}
10 \\
$\mathrm{~m}^{3} / \mathrm{fed}$
\end{tabular} & \multicolumn{2}{|c|}{\begin{tabular}{c|c}
15 \\
$\mathrm{~m}^{3} / \mathrm{fed}$
\end{tabular}} & Mean (B) \\
\hline & \multicolumn{11}{|c|}{ Fixed oil yield/feddan (liter/feddan) } \\
\hline Control & 132.00 & 69.78 & 97.33 & 121.33 & 105.11 & 146.67 & 71.56 & \multicolumn{2}{|c|}{100.00} & 124.00 & 110.56 \\
\hline R1 (200 ppm) & 162.67 & 111.56 & 143.11 & 160.89 & 144.56 & 169.78 & 115.56 & \multicolumn{2}{|c|}{148.00} & 167.56 & 150.23 \\
\hline R2 (300 ppm) & 263.89 & 136.89 & 203.11 & 235.11 & 209.75 & 240.89 & 139.56 & 207.5 & & 238.22 & 206.56 \\
\hline SAL1 (100 ppm) & 173.78 & 120.00 & 148.44 & 172.44 & 153.67 & 180.44 & 128.00 & 154.6 & & 178.22 & 160.33 \\
\hline SAL2 (200 ppm) & 211.11 & 130.67 & 169.33 & 209.78 & 180.22 & 219.56 & 138.22 & 176.0 & & 215.56 & 187.34 \\
\hline $\mathrm{Y} 1(5 \mathrm{~g} / \mathrm{l})$ & 169.33 & 111.11 & 145.33 & 168.44 & 148.56 & 179.11 & 115.11 & 150.2 & & 177.33 & 155.44 \\
\hline Y2 (10 g/l) & 217.78 & 139.56 & 187.56 & 215.56 & 190.12 & 227.11 & 146.22 & 195.1 & & 224.00 & 198.11 \\
\hline Mean $(A)$ & 190.08 & 117.08 & 156.32 & 183.36 & & 194.79 & \begin{tabular}{l|l}
9 & 107.18 \\
\end{tabular} & 161.6 & & 189.27 & \\
\hline L.S.D. at $5 \%$ & $\mathrm{~A}:$ & \begin{tabular}{|l|l|}
.75 & \\
\end{tabular} & B: 10.1 & & $A B: 20.2$ & & 5.80 & B: 7. & & & AB: 14.62 \\
\hline & & & & & & $\mathrm{N} \%$ & & & & & \\
\hline Control & 2.28 & 1.93 & 2.05 & 2.18 & 2.11 & \begin{tabular}{l|l} 
& 2.40 \\
\end{tabular} & 2.05 & 2.20 & & 2.30 & 2.24 \\
\hline R1 (200 ppm) & 2.57 & 2.28 & 2.37 & 2.43 & 2.41 & 2.65 & 2.30 & 2.43 & & 2.56 & 2.49 \\
\hline R2 (300 ppm) & 2.67 & 2.43 & 2.56 & 2.65 & 2.58 & 2.75 & 2.53 & 2.62 & & 2.68 & 2.65 \\
\hline SAL1 (100 ppm) & 2.61 & 2.30 & 2.40 & 2.50 & 2.45 & 2.68 & 2.43 & 2.53 & & 2.62 & 2.57 \\
\hline SAL2 (200 ppm) & 2.74 & 2.50 & 2.58 & 2.62 & 2.61 & 2.85 & 2.56 & 2.68 & & 2.75 & 2.71 \\
\hline $\mathrm{Y} 1(5 \mathrm{~g} / \mathrm{l})$ & 2.55 & 2.20 & 2.30 & 2.40 & 2.36 & 2.62 & 2.25 & 2.40 & & 2.53 & 2.45 \\
\hline Y2 (10 g/l) & 2.83 & 2.56 & 2.65 & 2.71 & 2.69 & 2.88 & 2.62 & 2.71 & & 2.80 & 2.75 \\
\hline Mean $(A)$ & 2.61 & 2.31 & 2.42 & 2.50 & & 2.69 & \begin{tabular}{l|l|} 
& 2.39 \\
\end{tabular} & 2.51 & & 2.61 & \\
\hline L.S.D. at $5 \%$ & A: 0 & .042 & B: 0.03 & & AB: N.S. & A: & 0.041 & B: 0.0 & 035 & & AB: N.S. \\
\hline R: Royal jelly & SAL & : Salicy & lic acid & $\mathrm{Y}:$ ActiV & ve dry yeas & & & & & & \\
\hline
\end{tabular}

Table 8. Influence of organic, NPK and bio-fertilization as well as natural substances on phosphorus and potassium percentages of Nigella sativa, L. plants.

\begin{tabular}{|c|c|c|c|c|c|c|c|c|c|c|}
\hline \multirow{3}{*}{$\begin{array}{l}\text { Spraying } \\
\text { treatments } \\
\text { (B) }\end{array}$} & \multicolumn{10}{|c|}{ Chicken manure $\left(\mathrm{m}^{3} /\right.$ fed.) $(\mathrm{A})$} \\
\hline & \multicolumn{5}{|c|}{ First season $(2009 / 2010)$} & \multicolumn{5}{|c|}{ Second season $(2010 / 2011)$} \\
\hline & NPK & $\begin{array}{c}5 \\
\mathrm{~m}^{3} / \mathrm{fed}\end{array}$ & $\begin{array}{c}10 \\
\mathrm{~m}^{3} / \mathrm{fed}\end{array}$ & $\begin{array}{c}15 \\
\mathrm{~m}^{3} / \mathrm{fed}\end{array}$ & $\begin{array}{c}\text { Mean } \\
\text { (B) }\end{array}$ & NPK & $\begin{array}{c}5 \\
\mathrm{~m}^{3} / \mathrm{fed} .\end{array}$ & $\begin{array}{c}10 \\
\mathrm{~m}^{3} / \mathrm{fed}\end{array}$ & $\begin{array}{c}15 \\
\mathrm{~m}^{3} / \mathrm{fed}\end{array}$ & $\begin{array}{c}\text { Mean } \\
\text { (B) }\end{array}$ \\
\hline & \multicolumn{10}{|c|}{$\mathbf{P} \%$} \\
\hline Control & 0.293 & 0.144 & 0.179 & 0.220 & 0.209 & 0.304 & 0.152 & 0.166 & 0.231 & 0.213 \\
\hline R1 (200 ppm) & 0.433 & 0.209 & 0.350 & 0.405 & 0.349 & 0.428 & 0.214 & 0.362 & 0.415 & 0.355 \\
\hline R2 (300 ppm) & 0.460 & 0.399 & 0.407 & 0.436 & 0.426 & 0.470 & 0.340 & 0.428 & 0.438 & 0.419 \\
\hline SAL1 (100 ppm) & 0.361 & 0.176 & 0.244 & 0.325 & 0.277 & 0.390 & 0.168 & 0.251 & 0.335 & 0.286 \\
\hline SAL2 (200 ppm) & 0.440 & 0.250 & 0.379 & 0.420 & 0.372 & 0.438 & 0.248 & 0.390 & 0.435 & 0.378 \\
\hline Y1 $(5 \mathrm{~g} / \mathrm{l})$ & 0.419 & 0.183 & 0.320 & 0.344 & 0.317 & 0.422 & 0.196 & 0.350 & 0.353 & 0.329 \\
\hline Y2 (10 g/l) & 0.455 & 0.258 & 0.416 & 0.432 & 0.390 & 0.443 & 0.271 & 0.409 & 0.425 & 0.387 \\
\hline Mean $(A)$ & 0.409 & 0.231 & 0.328 & \multicolumn{2}{|l|}{0.369} & 0.414 & 0.226 & 0.337 & 0.375 & \\
\hline \multirow[t]{2}{*}{ L.S.D. at $5 \%$} & \multicolumn{2}{|c|}{\begin{tabular}{l|l} 
A: 0.042 & \\
\end{tabular}} & B: 0.039 & \multicolumn{2}{|c|}{\begin{tabular}{l|l} 
& AB: N.S. \\
\end{tabular}} & \multicolumn{2}{|c|}{ A: 0.041} & B: 0.035 & \multicolumn{2}{|c|}{ AB: N.S. } \\
\hline & \multicolumn{10}{|c|}{$\mathbf{K} \%$} \\
\hline Control & 2.267 & 2.116 & 2.223 & 2.251 & 2.214 & 2.273 & 2.223 & 2.239 & 2.265 & 2.250 \\
\hline R1 (200 ppm) & 2.410 & 2.361 & 2.395 & 2.400 & 2.392 & 2.420 & 2.370 & 2.396 & 2.410 & 2.399 \\
\hline R2 (300 ppm) & 2.560 & 2.431 & 2.501 & 2.525 & 2.504 & 2.673 & 2.501 & 2.610 & 2.635 & 2.605 \\
\hline SAL1 (100 ppm) & 2.385 & 2.342 & 2.375 & 2.395 & 2.374 & 2.410 & 2.345 & 2.385 & 2.400 & 2.385 \\
\hline SAL2 (200 ppm) & 2.468 & 2.395 & 2.430 & 2.450 & 2.436 & 2.470 & 2.400 & 2.415 & 2.455 & 2.435 \\
\hline Y1 (5 g/l) & 2.450 & 2.375 & 2.400 & 2.410 & 2.409 & 2.455 & 2.385 & 2.401 & 2.430 & 2.418 \\
\hline Y2 (10 g/l) & 2.673 & 2.595 & 2.635 & 2.650 & 2.638 & 2.703 & 2.611 & 2.650 & 2.673 & 2.659 \\
\hline Mean (A) & 2.459 & 2.374 & 2.423 & 2.440 & & 2.486 & 2.405 & 2.442 & 2.467 & \\
\hline L.S.D. at $5 \%$ & A: 0 & & B: 0.098 & & N.S. & $\mathrm{A}:$ & & B: 0.051 & & N.S. \\
\hline R: Royal jelly & SAL & Sallcyi & acid & : Activ & dry ye: & & & & & \\
\hline
\end{tabular}

\section{References}

Abdalla, M. Y. A (2009) Effect of organic, bio. and mineral fertilization on growth, yield, oil productivity and chemical constituents of coriander plant. J. Agric. Sci. Mansoura Univ., 34(5), 5195 - 5208.

Abdou, M. A. H., Attia, F. A., Ahmed, E. T. and Abd El-Naeem, L. (2009a) Response of caraway plants to some organic, antioxidants and biofertilization treatments. The fourth Inter. Enveron. Conf., Mansoura Univ., on Environmental and healthy safety, 28 - 29 October.
Abdou. M. A. H., Attia, F. A., Taha, R. A. and Tanious, C. T. S. (2009b) Effect of some organic, bio-fertilization and antioxidant treatments on fennel plants. The fifth Inter. of Sustain., Agric. and Develop. Fac. of Agric., Fayoum Univ., 21 - 23 December.

Ahmed, E. F. A. (2007) Evaluation of certain fertilizing programs on anise and black cumin plants. Ph.D. Thesis Fac. Assiut Univ. Egypt.

Ali, A. F. (2004) The benefits of using some natural sources of phosphate and salicylic acid on Tagetes minuta, L. plants, Minia J. of Agric Res. Develop., (24), 4pp 621-648. 
Al-Shareif, A. M. O. (2006) Response of caraway plants grown in sandy soil under drip irrigation system to some bio-fertilization and anti-oxidant treatments. M. Sc. Thesis, Fac. Agric., Minia Univ. Egypt.

Aly, M. K., Mohamed, M. A. H., Attia, F. A., ElSayed, A. A. and Abd El-Gawad, M. H. I (2007a) Effect of some organic and biofertilization treatments on coriander plants. 1Vegetative growth and yield. Proc. 1st Inter. Conf. Desert. Cultivation, Problems and solutions, Minia Univ. Egypt, 27 -29 March, p: $101-111$.

Aly, M. K., Mohamed, M. A. H., Attia, F. A., ElSayed, A. A. and Abd El-Gawad, M. H. I. (2007b) Effect of some organic and biofertilization treatments on coriander plants. 2Chemical composition. Proc. 1st Inter. Conf. Desert. Cultivation, Problems and solutions, Minia Univ. Egypt, 27 -29 March, in press.

A.O.A.C. (1980) Association of Official Analysis of the Association of Official and Agricultural Chemists (A.O.A.C.) 12th Ed. Washington, D.C.

Ayat, M. M. (2007) Effect of fertilization with macro, micro nutrients and antioxidants on coriander (Coriandrum sativum, L.) plants grown in new reclaimed land. M. Sc. Thesis, Fac. Agric. Minia Univ. Egypt.

Bowe, R., Seidel, H. and Viogt, B. (1989) On the effect of dried yeast products as slow release fertilizers. Archiv fur Gartenbau, 37(5), 361 369 (C.F. Hort. Abst., Vol. 60, 9968).

British Pharmacopeia (1963) Determination of Volatile Oil Drugs. The pharmaceutical press, London.

Buchula, A. and Schmid, A. (1979) Vitamin B and its analogous as new class $\mathrm{F}$ plant growth substances affecting rhizogensis. Nature, 280, $230-231$.

Cottenie, A., Verloo, M., Velghe, $M$ and Camerlynck (1982) Chemical analysis of Plant and Soils. Laboratory of Analytical and Agrochemistry, State Univ., Ghent, Belgium.

Develin, R. M. (1975) Plant physiology. 3rd Dd. Affiliated East - West Press Pvt Ltd. New Delhi.

El-Maziny, M. Y. and Hassan, M. N. (1990) Effect of royal jelly, vitamin B complex and ethrel on the productivity of cucumber. Minia J. Agric., Res. and Dev., 12(3), 1901 -1909.

El-Shaikha, K.A.A. (2010): Growth and yield of some cucumber cultivators as affected by plant density and royal jelly application. J. of Hort. Sci. \& Orn. Plants, 2(2), 131-137.

Gordon, L., Minibayeva, F., Ogerodnikova, T. and Valitova, J. (2002) Salicylic acid induced dissipation of the proton gradient on the plant cell membrane. Doklady BIOI. Sci., 387, 581 - 583.

Haridi, S. M. M. (1987) Bio-chemical studies on sage plant (Salvia officinalis, L.) Ph. D. Thesis, Ain Shams Univ., Egypt.
Helmy, T. A. (2008) Effect of some organic and biofertilization treatments on black cumin plants $\mathrm{M}$. Sc. Thesis, Fac. Agric., Minia Univ., Egypt.

Hemdan, S. H. O. (2008) Effect of some organic and bio-fertilization treatments on anise plants. M. Sc. Thesis, Fac. Agric Minis Univ., Egypt.

Heyl, H. L. (1949) An observation suggesting the presence of gonadotrofic hormone in royal jelly. Science, 89, $590-591$.

Ibrahim, T. I. E. (2010) Physiological studies on geranium plants. M.Sc. Thesis Fac. Agric. Minia Univ., Egypt.

Jackson, M. L. (1973) Soil Chemical Analysis Prentice-Hall of India Private Limited M-97, New Delhi, India, 498pp.

Khan, W., Prithviraj, B. and Smith, D. (2003) Photosynthetic responses of corn and soy been to foliar application of salicylates J. plant physiol., 160, 485 - 492.

Larson, P. A., Herbo, A., Klangson, S. and Ashain, T. (1962), On the biogenesis of some compounds in Acetobacter xylium . Plant physiol. 15, $552-565$.

Mohamed, A. A. and Ahmed, M. E. (2002) Acomparative study on the effect of sugar cane filter mud, sheep and chicken manures used for fertilization of sweet fennel crop (Foeniculum vulgare, L.). Minia J. Agric. Res. \& Develop., 22(3), 221 - 234.

Mohamed, M. A. H. and Abdou, M. A. H. (2004) Growth and oil production of fennel (Foeniculum vulgare, Mill) : Effect of irrigation and organic fertilization. Biological Agriculture and Horticulture, Vol. 22, pp. 31 -39.

M STAT-C (1986) A microcomputer program for the design management and analysis of agronomic research experiments (version 4), Michigan State Univ., USA.

Naguib, N. Y. and Khalil, M. Y. (2002) Studies on the effect of dry yeast thiamine and biotin on the growth and chemicals constituents of black cumin (Nigella sativa, L.) Arab Univ. J. Agric. Sci. Ain Shams Univ. Cairo, 10(3), 919 - 937.

Nation, J. L and Robinson, F. A (1971) Concentration of some major and trace elements in honey bee, royal jelly and pollen. J. Apic. Res., 10(1), 35 - 43.

Shalan, M. N. (2005) Influence of bio-fertilization and chicken manure on growth, yield and seeds quality of Nigella sativa, L. plants. Egypt. J. Agric. Res., 83(2), $811-828$.

Townsend, G. and Lucas, C. (1940) The chemical natural of royal jelly. Bio-chemical J., 34, 1115 1162.

Ustun, G., Kent, L., Cekin, N. and Civenlekoglu, H. (1999) Investigation of technological of Nigella sativa, L. (black cumin) seed oil. JAOCS, 67(12), $71-86$ 


\section{تأثير التسميد العضوى والمعدنى والحيوى ومعاملات مواد طبيعية على نبات حبة البركة}

محمود عبد الهادي حسن عبده1 ، رجاء على طه1 ، ريم محمد الحسينى عبد الرؤوف 2 ـ رنده محمد صلاح الدين1

قسم البساتين ـ كلية الزراعة - جامعة المنيا ${ }^{2}$ ـ معهُ البساتين ( النباتات الطبية والعطرية ) مركز البحوث الزراعية ـ مصر .

أجريت هذه التجربة لدراسة تأثير السماد العضوى (زرق الدواجن) والمعنى (ن ، فو ، بو ) (كعامل رئيسى ) والحيوى (الخميرة الجافة )

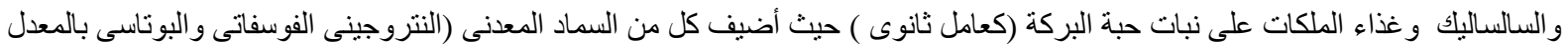

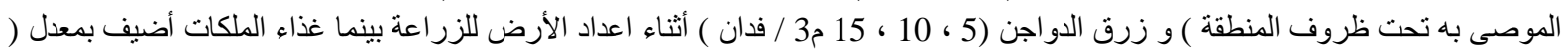

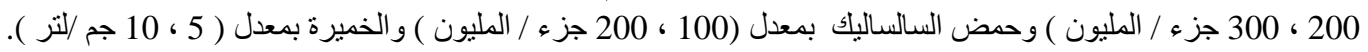

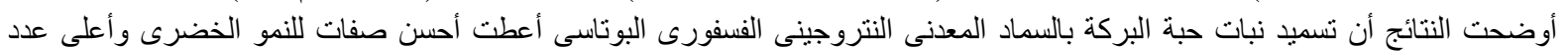

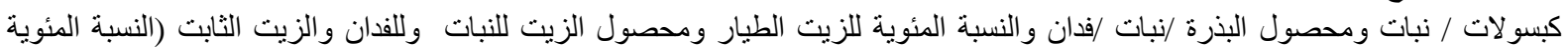

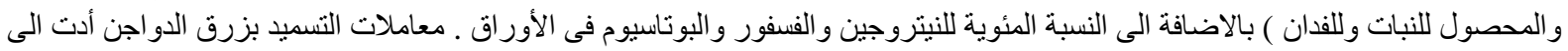

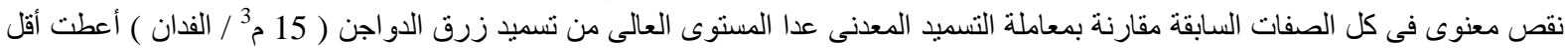

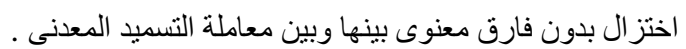

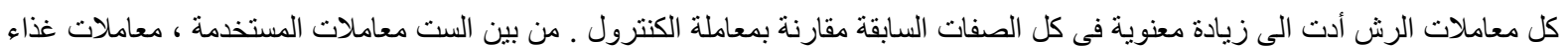

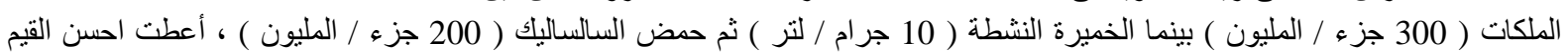

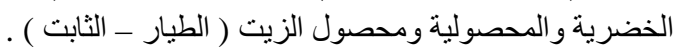

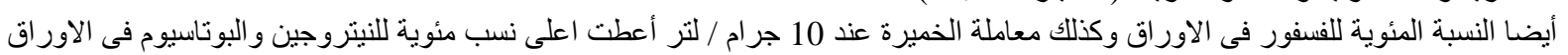

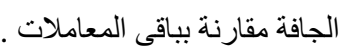
كانت معاملات التفاعل بين العامل الرئيسى ، والعامل الثانئ الثانوى الاكثر فاعلية على نتائج القياسات ، حيث سجلت اعلى القيات القيم فى جميع القياسات محل

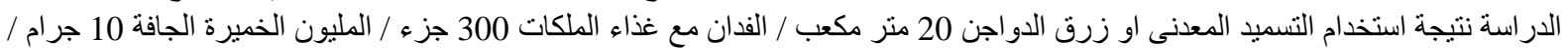

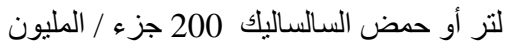

